\title{
Postprandial lipaemia is exacerbated in fat-cholesterol-fed rabbits: relationship to atheroma deposition
}

\author{
BY CHRISTINE JUHEL ${ }^{1}$, CHRISTOPHE DUBOIS ${ }^{1}$, MICHELE SENFT ${ }^{1}$, EMILE LEVY ${ }^{2}$, \\ HUGUETTE LAFONT $^{1}$ AND DENIS LAIRON ${ }^{1 *}$ \\ ${ }^{1}$ Unité 130-INSERM (Institut National de la Santé et de la Recherche Médicale), 13009 Marseille, France \\ ${ }^{2}$ Hôpital Sainte-Justine, Centre de Recherche Pédiatrique, Gastroentérologie-Nutrition, Montréal, \\ Québec, H3T 1C5, Canada
}

(Received 19 August 1996 - Revised 2 January 1997 - Accepted 9 January 1997)

\begin{abstract}
The aim of the present study was to evaluate the links between chronic fat-cholesterol intake, postprandial lipaemia and atherogenesis in New Zealand White rabbits. Adult rabbits were fed on either a low-fat control diet (LF) or a high-fat, high-cholesterol diet (HF). Rabbits received a test meal containing $\left[{ }^{3} \mathrm{H}\right]$ cholesterol and $\left[{ }^{14} \mathrm{C}\right]$ triolein on days 0 and 63 for the $\mathrm{LF}$ group and days 14, 28, 42,63 and 84 for the HF group. Blood was collected $24 \mathrm{~h}$ post-absorptively and 10, 24, 34 and $48 \mathrm{~h}$ after test-meal intake. Post-absorptive as well as postprandial lipoproteins and lipaemia were not modified in the LF rabbits, who did not show any atheroma deposition on day 119. In HF rabbits, postprandial plasma triacylglycerols peaked $24-34 \mathrm{~h}$ after meal intake. The $0-48 \mathrm{~h}$ areas under the curves of triacylglycerol and triacylglycerol-rich lipoproteins (TRL) steadily increased with time of chronic lipid feeding with values significantly higher than those in the LF rabbits. The postprandial plasma and TRL concentrations of dietary radiolabelled lipids were significantly higher in HF than LF rabbits. Post-heparin lipoprotein lipase (EC 3.1.1.34) and hepatic lipase (EC 3.1.1.3) activities were twofold higher in HF rabbits than in LF rabbits at day 105 . In HF rabbits, a marked atheroma plaque deposition in the aorta was observed (30.9 (SE 3.9) \% of total surface). The extent of atheroma deposition was positively correlated to the postprandial responses of plasma total triacylglycerols and dietary-derived lipids as well as total cholesterol and dietary-derived cholesterol in HF rabbits. In conclusion, chronic ingestion of a HF diet led to marked increases in postprandial lipaemia and TRL particles, and atheroma deposition.
\end{abstract}

Postprandial lipaemia: Dietary lipids: Hypercholesterolaemic rabbits

Since the claim of Zilversmit (1979) that atherosclerosis may be a postprandial phenomenon, much knowledge has been obtained on postprandial lipaemia and lipoproteins during the last decade, as reviewed (Karpe \& Hamsten, 1995; Lairon, 1996). For instance, recent findings support the concept that some post-absorptive dyslipaemic conditions or myocardial infarctions are associated with abnormal postprandial patterns in human subjects (Simpson et al. 1990; Patsch et al. 1992; Karpe \& Hamsten, 1995). Because the postprandial hyperlipidaemic state lasts most of the day in human subjects, alteration in the postprandial response after ingestion of selected food components, and especially lipids (Dubois et al. 1994; Murphy et al. 1995), should be regarded as an early metabolic event potentially related to atherosclerosis.

In addition to human studies, postprandial studies have essentially been performed in the rat (Redard et al. 1992) and the pig (Luhman et al. 1992) which are not species that develop atherosclerosis quickly. In contrast, the rabbit has been widely used as an animal model for chronic feeding studies, because of its exacerbated sensitivity to dietary fat and

\footnotetext{
* For reprints.
} 
cholesterol and ability to develop atheroma deposition (Kritchevsky, 1991). Some known metabolic discrepancies between rabbits and human subjects (Warren et al. 1991; Chang \& Bornsztajn, 1993) could be involved in the higher susceptibility to dietary lipids exhibited by the rabbit.

In addition to the unique postprandial experiment already performed in rabbits to evaluate the effects of different sources of dietary triacylglycerols (Van Heek \& Zilversmit, 1990), the present study was therefore performed in New Zealand White rabbits to evaluate the possible links between chronic fat and cholesterol feeding, postprandial handling of dietary lipids, lipaemia and lipoproteins, and atherogenesis.

\section{MATERIALS AND METHODS}

\section{Animals and diets}

Thirteen New Zealand White male rabbits (Elevage Scientifique des Dombes, Romans, France), $12-13$ weeks old and weighing $2 \cdot 20-2.40 \mathrm{~kg}$ at the beginning of the experiment were used. They were housed individually at $20^{\circ}$, exposed to a $12 \mathrm{~h}$ light-dark cycle and had free access to water and food. The animals were randomly assigned to two groups. A group of six rabbits was fed on a low-fat (LF) semi-purified diet (UAR 112) containing $(\mathrm{g} / \mathrm{kg})$ : protein 130 , cellulose 160 , carbohydrate 495 , vegetable fat 27 , regular UAR-205 mineral and vitamin mixture 80 and water 105 (UAR, Villemoison sur Orge, France). A group of seven rabbits was fed on a high-fat, high-cholesterol semi-purified diet (HF), prepared in our laboratory from the LF diet, containing $(\mathrm{g} / \mathrm{kg})$ : lard 52 , cholesterol 1.7 , protein 102 , cellulose 129 , carbohydrate 258 , regular UAR-205 mineral and vitamin mixture 59 and water 398 . The LF diet and the HF diet provided 2200 and $1920 \mathrm{~kJ} / \mathrm{kg}$ respectively. The overall study lasted 17 weeks $(119 \mathrm{~d})$. Food intakes were similar in the two groups of rabbits (143 (SE 9) $\mathrm{g} / \mathrm{d}$ and 132 (SE 7) g/d respectively) as were body weights at day $119(4.0$ (SE 0.2$) \mathrm{kg}$ and 3.7 (SE 0.1$) \mathrm{kg}$ respectively).

\section{Test meals}

The LF rabbits were given a test meal on days 0 and 63 . The HF rabbits received five test meals, on days 14 (HF-TM1), 28 (HF-TM2), 42 (HF-TM3), 63 (HF-TM4) and 84 (HFTM5). On the morning of the experiment, after being deprived of food for $24 \mathrm{~h}$, the rabbits in the two experimental groups were set in restraining cages and ingested a $25 \mathrm{~g}$ test meal as an intrabuccal bolus given with a $20 \mathrm{ml}$ plastic syringe within $20 \mathrm{~min}$. The test meals contained $(\mathrm{g} / \mathrm{kg})$ : casein 90 , sucrose 90 , starch 120 , peanut oil 240 , cholesterol 8 , phospholipids 12, mineral and vitamin mixture 85 and water 355 . All test meals except those given on days 28 and 63 in the $\mathrm{HF}$ group contained $\left[{ }^{3} \mathrm{H}\right]$ cholesterol $\left(1.85 \mathrm{MBq} / \mathrm{g}\right.$ cholesterol) and $\left[{ }^{14} \mathrm{C}\right]$ triolein $(0.002 \mathrm{MBq} / \mathrm{g}$ peanut oil) purchased from CEA (Gif-sur-Yvette, France).

\section{Analytical determinations}

Blood was collected, in tubes containing EDTA, from the ear artery $24 \mathrm{~h}$ after fooddeprivation and 10, 24, 34 and $48 \mathrm{~h}$ after test-meal intake. In preliminary experiments, we observed that radiolabelled dietary lipids did not noticeably appear in the plasma during the first $10 \mathrm{~h}$ period. To avoid bacterial growth and proteolysis, a cocktail of inhibitors was added to plasma samples (Cardin et al. 1984). Blood was centrifuged for $15 \mathrm{~min}$ at $910 \mathrm{~g}$ at room temperature and plasma stored at $-20^{\circ}$ until analysis. 
Triacylglycerols were determined by an enzymic procedure (Buccolo \& David, 1973) using commercial kits (Kits BioMérieux, Marcy l'Etoile, France). Total and free cholesterol were assayed by the cholesterol oxidase (EC 1.1.3.6) method (Seidel et al. 1983) with kits purchased from BioMérieux. Plasma phospholipids were assayed by an enzymic procedure (Takayama et al. 1977) with commercial kits (BioMérieux). Radiolabelled dietary and plasma lipids were measured by scintillation counting with a Packard 1600TR instrument (Packard, Meriden, CT, USA) with an external standard for quench correction.

A $1 \mathrm{ml}$ portion of plasma ( $24 \mathrm{~h}$ post-absorptive and $34 \mathrm{~h}$ postprandial peak samples) was used for the separation of three lipoprotein fractions, i.e. triacylglycerol-rich lipoproteins (TRL; composed of chylomicrons, VLDL and intermediate-density lipoproteins) (density (d) $\leq 1.019 \mathrm{~kg} / \mathrm{l})$ ), LDL $\quad(1.019 \leq \mathrm{d} \leq 1.063 \mathrm{~kg} / \mathrm{l})$ and HDL $(1.063 \leq \mathrm{d} \leq 1.21 \mathrm{~kg} / \mathrm{l})$ by ultracentrifugation on a $\mathrm{KBr}$ discontinuous gradient for $24 \mathrm{~h}$ at $200000 \mathrm{~g}$ and $15^{\circ}$ in an SW 41Ti rotor (Beckman, Palo Alto, CA, USA) as previously described (Redgrave et al. 1975). Lipoprotein lipid values were adjusted for ultracentrifugation recovery (triacylglycerols: 92.8 (SE 6.5)\%; cholesterol: 74.1 (SE $3.8) \%$; phospholipids: $76 \cdot 7$ (SE 4.2) \%).

\section{Lipoprotein lipase and hepatic lipase activities}

On day 105 , post-heparin blood samples were collected $20 \mathrm{~min}$ after a single injection of $200 \mathrm{IU}$ heparin $/ \mathrm{kg}$ (Héparine LEO, Paris, France) from the marginal ear vein at $4^{\circ}$ and then stored at $-20^{\circ}$. The lipolytic activities of portions $(150 \mu \mathrm{l})$ were measured on an emulsified radiolabelled substrate at two different $\mathrm{NaCl}$ concentrations $(0.15$ or $3.55 \mathrm{M})$ as reported (Van Heek \& Zilversmit, 1990). The $\left[{ }^{14} \mathrm{C}\right]$ oleic acid radioactivity was extracted (Belfrage \& Vaughan, 1969) and measured. Total lipase activity (low salt) and hepatic lipase (EC 3.1.1.3) activity (high salt) were measured (mmol free fatty acids/l per min) and lipoprotein lipase (EC 3.1.1.34) activity was calculated as the difference.

\section{Stomach, small intestine and liver lipids}

At the end of the experiment (day 119), rabbits were killed with an overdose of pentobarbital $34 \mathrm{~h}$ after ingestion of a test meal containing $\left[{ }^{3} \mathrm{H}\right]$ cholesterol and $\left[{ }^{14} \mathrm{C}\right]$ triolein. The stomach and small intestine were clamped and their contents collected as previously described (Borel et al. 1989). $\left[{ }^{3} \mathrm{H}\right]$ and $\left[{ }^{14} \mathrm{C}\right]$ radioactivities of the contents were counted.

The liver was excised, rinsed with $0.15 \mathrm{M}-\mathrm{NaCl}$, frozen and kept at $-20^{\circ}$. After thawing, a small piece of liver was ground in ethanol with a polytron (Kriens, Luzern, Switzerland) and lipids extracted with chloroform-methanol $(2: 1, \mathrm{v} / \mathrm{v})$ by the method of Folch et al. (1957). Neutral lipids were separated by TLC and quantified by using video densitometry as previously described (Armand et al. 1994).

\section{Atheroma plaque quantification}

Immediately after killing, the arteries were carefully isolated from arch of aorta to iliac section. Lipids were removed on the external side of the aortas. Aortas were cut in the longitudinal axis, fixed in formol $(100 \mathrm{ml} / \mathrm{l})$ overnight and stained for $20 \mathrm{~min}$ in red sudan IV as previously described (Holman et al. 1958). Total aorta surface and surface covered 
by stained atherosclerotic lesions were quantified by using video densitometry and the BioLab software package as described by Armand et al. (1994).

\section{Statistical analysis}

The statistical significance $(P<0.05)$ of the differences observed between the two groups of rabbits was assessed by using ANOVA for factorial values and the Fisher test (Winer, 1971). The post-meal values (means with their standard errors) are expressed as variations of concentration over baseline (post-absorptive baseline values being zero). LF test-meal values are given as the mean of the two test meals performed in the LF rabbits (days 0 and 63). The areas under the $0-48 \mathrm{~h}$ curves (AUC) were calculated by the trapezoidal method. In a given group of rabbits, the statistical significance $(P<0.05)$ of the differences observed between the experimental meals (individual time points or AUC) or $24 \mathrm{~h}$ postabsorptive values were assessed by using ANOVA for repeated values. Correlation coefficients were obtained from linear regression analyses. The Stat-View II microcomputer program (Abacus, Berkeley, CA, USA) was used.

\section{RESULTS}

\section{Post-absorptive plasma lipids and lipoproteins}

The $24 \mathrm{~h}$ post-absorptive plasma triacylglycerol concentrations measured in the rabbits fed on the LF diet remained unchanged throughout the testing period $(0.72$ (SE 0.09) mmol/1). In the rabbits fed on the HF diet, the plasma triacylglycerol concentrations were higher at one time point but were on the whole unchanged $(0.91$ (SE 0.06$) \mathrm{mmol} / \mathrm{l}$; range: 0.59 $1.21 \mathrm{mmol} / \mathrm{l})$. The plasma concentrations of esterified cholesterol, free cholesterol and phospholipids were unchanged over the course of the study in the rabbits fed on the LF diet. In contrast, in the $\mathrm{HF}$ rabbits, $24 \mathrm{~h}$ post-absorptive plasma cholesterol levels steadily increased with time of feeding and reached a plateau after $63 \mathrm{~d}(34.9$ (SE 1.8) mmol/l), i.e. seventeen times greater than in the LF rabbits. The post-absorptive plasma phospholipid concentrations were also higher $(P<0.05)$ from day 28 on the HF diet and reached 6.2 (SE $0.4) \mathrm{mmol} / 1$ compared with 1.5 (SE 0.1$) \mathrm{mmol} / 1$ in LF rabbits.

In rabbits fed on the LF diet, HDL and LDL contained mostly triacylglycerols and esterified cholesterol (Table 1). In rabbits fed on the HF diet for $14 \mathrm{~d}$, the triacylglycerol, total, free and esterified cholesterol concentrations of post-absorptive TRL significantly increased $(P<0.05)$ (Table 1$)$. From day $42, \beta$-VLDL accumulated in the plasma and contained most of the lipid species. Post-absorptive HDL and LDL triacylglycerols did not change markedly whereas HDL free and esterified cholesterol levels significantly increased after $14 \mathrm{~d}$ of fat-cholesterol feeding.

\section{Postprandial plasma lipid responses}

The postprandial plasma lipid responses were not different after the two test meals performed in LF rabbits, on days 0 and 63 (mean of pooled values obtained after the two test meals (LF-TM) are given for clarity). As shown in Fig. 1, LF rabbits showed a small but significant increase in triacylglycerol level $(0.24$ (SE 0.10$) \mathrm{mmol} / \mathrm{l}) 24 \mathrm{~h}$ after test-meal intake (LF-TM, Fig. 1). In HF rabbits, postprandial plasma triacylglycerol concentrations were significantly higher compared with LF rabbits after $14 \mathrm{~d}$ (HF-TM1) on a lipid diet. After the first three test meals (HF-TM1 to HF-TM3), plasma triacylglycerols peaked at 
Table 1. Lipoprotein lipids in post-absorptive $(0 \mathrm{~h})$ and postprandial $(34 \mathrm{~h})$ blood samples ( $\mathrm{mmol} / \mathrm{l}$ ) from rabbits fed on low-fat (LF) and high-fat, high-cholesterol (HF) diets $\dagger$

(Mean values with their standard errors for six (LF) or seven (HF) rabbits)

\begin{tabular}{|c|c|c|c|c|c|c|c|c|c|}
\hline \multirow{3}{*}{$\begin{array}{l}\text { Lipoprotein } \\
\text { lipids }\end{array}$} & & \multicolumn{8}{|c|}{ Experimental time-point } \\
\hline & & \multicolumn{2}{|c|}{$\begin{array}{c}\text { LF-TM } \\
(0,63 \mathrm{~d})\end{array}$} & \multicolumn{2}{|c|}{$\begin{array}{c}\text { HF-TM1 } \\
\text { (14d) }\end{array}$} & \multicolumn{2}{|c|}{$\begin{array}{c}\text { HF-TM3 } \\
\text { (42d) }\end{array}$} & \multicolumn{2}{|c|}{$\begin{array}{l}\text { HF-TM5 } \\
\text { (84 d) }\end{array}$} \\
\hline & & Mean & SE & Mean & SE & Mean & $\mathrm{SE}$ & Mean & SE \\
\hline TRL $\ddagger 0 \mathrm{~h}$ & $\begin{array}{l}\mathrm{TG} \\
\mathrm{TC} \\
\mathrm{PL}\end{array}$ & $\begin{array}{l}0.03^{\mathrm{a}} \\
0 \cdot 10^{\mathrm{a}} \\
0.02^{\mathrm{a}}\end{array}$ & $\begin{array}{l}0.01 \\
0.03 \\
0.01\end{array}$ & $\begin{array}{l}0.10^{\mathrm{b}} \\
0.85^{\mathrm{b}} \\
0.17^{\mathrm{a}}\end{array}$ & $\begin{array}{l}0.01 \\
0.15 \\
0.01\end{array}$ & $\begin{array}{r}0.60^{c} \\
11.01^{b} \\
1.89^{b}\end{array}$ & $\begin{array}{l}0.08 \\
0.97 \\
0.45\end{array}$ & $\begin{array}{r}0.68^{\mathrm{c}} \\
16.29^{\mathrm{c}} \\
4.01^{\mathrm{c}}\end{array}$ & $\begin{array}{l}0.07 \\
2.45 \\
0.54\end{array}$ \\
\hline LDL $0 \mathrm{~h}$ & $\begin{array}{l}\text { TG } \\
\text { TC } \\
\text { PL }\end{array}$ & $\begin{array}{l}0.15 \\
0.76^{\mathrm{a}} \\
0.69\end{array}$ & $\begin{array}{l}0.04 \\
0.10 \\
0.07\end{array}$ & $\begin{array}{l}0.25 \\
7.07^{b} \\
0.99\end{array}$ & $\begin{array}{l}0.10 \\
1.06 \\
0.34\end{array}$ & $\begin{array}{l}0.28 \\
9.89^{b} \\
0.85\end{array}$ & $\begin{array}{l}0.08 \\
1.98 \\
0.20\end{array}$ & $\begin{array}{l}0.17 \\
2.51^{c} \\
0.58\end{array}$ & $\begin{array}{l}0.03 \\
0.23 \\
0.09\end{array}$ \\
\hline $\mathrm{HDL} O \mathrm{~h}$ & $\begin{array}{l}\text { TG } \\
\text { TC } \\
\text { PL }\end{array}$ & $\begin{array}{l}0.48^{\mathrm{a}} \\
0.84^{\mathrm{a}} \\
0.26^{\mathrm{a}}\end{array}$ & $\begin{array}{l}0.03 \\
0.14 \\
0.02\end{array}$ & $\begin{array}{l}0.22^{\mathrm{b}} \\
0.37^{\mathrm{b}} \\
0.34^{\mathrm{a}, \mathrm{b}}\end{array}$ & $\begin{array}{l}0.07 \\
0.04 \\
0.05\end{array}$ & $\begin{array}{l}0.10^{\mathrm{b}} \\
0.57^{\mathrm{a}} \\
0.44^{\mathrm{b}}\end{array}$ & $\begin{array}{l}0.02 \\
0.05 \\
0.12\end{array}$ & $\begin{array}{l}0.24^{\mathrm{b}} \\
1.05^{\mathrm{a}} \\
0.44^{\mathrm{b}}\end{array}$ & $\begin{array}{l}0.10 \\
0.19 \\
0.08\end{array}$ \\
\hline $\mathrm{TRL} \ddagger 34 \mathrm{~h}$ & $\begin{array}{l}\text { TG } \\
\text { TC } \\
\text { PL }\end{array}$ & $\begin{array}{l}0.36^{\mathrm{a}^{*}} \\
0.09^{\mathrm{a}} \\
0.44^{\mathrm{a}^{*}}\end{array}$ & $\begin{array}{l}0.11 \\
0.03 \\
0.04\end{array}$ & $\begin{array}{l}0.46^{a^{*}} \\
3 \cdot 31^{b^{*}} \\
0.67^{b^{*}}\end{array}$ & $\begin{array}{l}0.10 \\
0.17 \\
0.02\end{array}$ & $\begin{array}{r}1.37^{\mathrm{b}^{*}} \\
18.65^{\mathrm{c} *} \\
3.37^{\mathrm{c}}\end{array}$ & $\begin{array}{l}0.12 \\
2.70 \\
0.85\end{array}$ & $\begin{array}{r}1.70^{b^{*}} \\
18.43^{\mathrm{c}} \\
3.83^{\mathrm{c}}\end{array}$ & $\begin{array}{l}0.18 \\
2.08 \\
0.30\end{array}$ \\
\hline LDL $34 \mathrm{~h}$ & $\begin{array}{l}\text { TG } \\
\text { TC } \\
\text { PL }\end{array}$ & $\begin{array}{l}0.28^{\mathrm{a}} \\
0.76^{\mathrm{a}} \\
0.65^{\mathrm{a}}\end{array}$ & $\begin{array}{l}0.08 \\
0.12 \\
0.03\end{array}$ & $\begin{array}{l}0.48^{b^{*}} \\
4.82^{b^{*}} \\
0.74^{a}\end{array}$ & $\begin{array}{l}0.02 \\
0.61 \\
0.03\end{array}$ & $\begin{array}{l}0.47^{b^{*}} \\
1.81^{c^{*}} \\
0.39^{b}\end{array}$ & $\begin{array}{l}0.01 \\
0.24 \\
0.10\end{array}$ & $\begin{array}{l}0.10^{\mathrm{c}} \\
1.99^{\mathrm{c}} \\
0.64^{\mathrm{a}}\end{array}$ & $\begin{array}{l}0.01 \\
0.44 \\
0.06\end{array}$ \\
\hline HDL $34 \mathrm{~h}$ & $\begin{array}{l}\mathrm{TG} \\
\mathrm{TC} \\
\mathrm{PL}\end{array}$ & $\begin{array}{l}0.13^{\mathrm{a}^{*}} \\
0.84^{\mathrm{a}} \\
0.21^{\mathrm{a}}\end{array}$ & $\begin{array}{l}0.02 \\
0.14 \\
0.04\end{array}$ & $\begin{array}{l}0.34^{\mathrm{b}} \\
0.40^{\mathrm{b}} \\
0.29^{\mathrm{a}, \mathrm{b}}\end{array}$ & $\begin{array}{l}0.11 \\
0.08 \\
0.04\end{array}$ & $\begin{array}{l}0 \cdot 09^{\mathrm{a}} \\
0 \cdot 68^{\mathrm{a}} \\
0 \cdot 35^{\mathrm{a}, \mathrm{b}}\end{array}$ & $\begin{array}{l}0.03 \\
0.14 \\
0.07\end{array}$ & $\begin{array}{l}0.09^{\mathrm{a}} \\
0.56^{\mathrm{a}^{*}} \\
0.42^{\mathrm{b}}\end{array}$ & $\begin{array}{l}0.02 \\
0.08 \\
0.07\end{array}$ \\
\hline
\end{tabular}

TM, test meal; TG, triacylglycerols; TC, total cholesterol; PL, phospholipids; TRL, triacylglycerol-rich lipoproteins.

${ }_{a, b, c}$ Mean values within a row not sharing a common superscript letter were significantly different, $P<0.05$ (ANOVA for factorial non-repeated values and Fisher's test at a probability of $95 \%$ ).

* Mean values were significantly different from the corresponding postabsorptive $(0 \mathrm{~h})$ values, $P<0.05$ (ANOVA for factorial repeated values and Fisher's test at a probability of $95 \%$ ).

$\dagger$ LF-TM values are means of two test meals performed in rabbits fed on diet LF on days 0 and 63. HF-TM1, 3 and 5 are test meals performed on days 14, 42 and 84 respectively in rabbits fed on the HF diet. For details of diets and procedures, see pp. 302-303.

$\ddagger$ TRL include chylomicrons, VLDL and $\beta$-VLDL particles.

24-34 h and postprandial curves were broader. After HF-TM4 and HF-TM5, triacylglycerol concentrations peaked after $34 \mathrm{~h}$. In HF rabbits, the post-meal triacylglycerol $0-48 \mathrm{~h}$ AUC values (Fig. 1, (b)) steadily increased during the first 6 weeks (HF-TM1 to HF-TM3) of the experiment and were significantly higher than in LF rabbits. Significantly elevated postprandial values were further observed on HF-TM4 and HF-TM5, although they were less pronounced.

\section{Postprandial plasma lipoproteins}

Changes in lipid concentration among the different classes of lipoproteins in the postprandial state ( $34 \mathrm{~h}$ after test meal intake) are shown in Table 1 . In the LF rabbits, a ten-fold increase in TRL, triacylglycerols and phospholipids was observed postprandially as compared with the $24 \mathrm{~h}$ post-absorptive state. LDL lipid components did not vary postprandially, whereas the HDL-triacylglycerol concentration significantly decreased in 


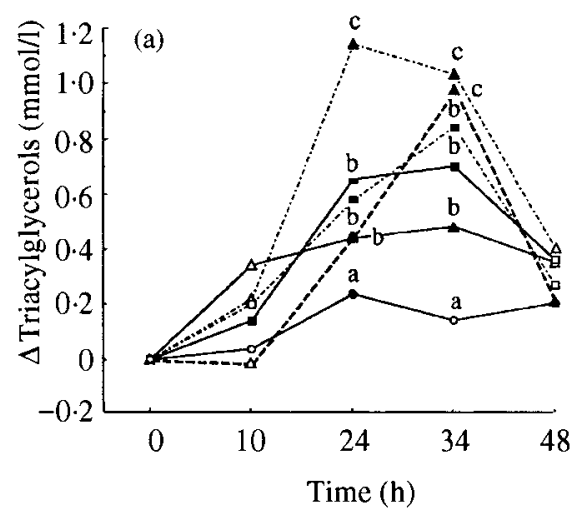

(b)

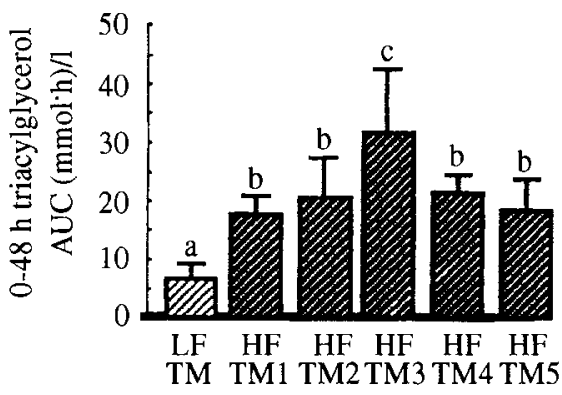

Fig. 1. (a) Plasma $0-48 \mathrm{~h}$ triacylglycerol responses to test meals containing $6 \mathrm{~g}$ fat and $0.2 \mathrm{~g}$ cholesterol given to rabbits fed on a low-fat control diet (LF-TM, $n 6,-\mathrm{O}$ ) or a high-fat, high-cholesterol diet (HF-TM1-5, $n$ 7). LF-TM values are means of test meals performed on days 0 and 63 . Test meals were given to rabbits of the HF group on days 14 (HFTM1, $-\triangle \longrightarrow$ ), 28 (HF-TM2, - $\square-$ ), 42 (HF-TM3, -- $\triangle--$ ), 63 (HF-TM4, - $\square--$ ) and 84 (HF-TM5, - $\triangle \triangle--$ ). Results are expressed as concentration changes $(\triangle)$ from post-absorptive values. Filled symbols indicate that the values were significantly different from postabsorptive values $(0 \mathrm{~h}$ ) for a given test meal (ANOVA for repeated values and Fisher's test at a probability of $95 \%$ ). ${ }^{a, b, c}$ Values bearing unlike letters were significantly different at a given time point (ANOVA for factorial non-repeated values and Fisher's test at a probability of $95 \%$ ). (b) Areas under the $0-48 \mathrm{~h}$ triacylglycerol curve (AUC) were calculated by the trapezoidal method. ${ }^{a, b, c}$ Values bearing unlike letters were significantly different, $P<0.05$.

the postprandial state, compared with the post-absorptive state. In the HF rabbits, postprandial TRL-triacylglycerols significantly increased over corresponding postabsorptive values and significantly more than those in the LF rabbits after 42,63 and $84 \mathrm{~d}$. Other TRL components, i.e., phospholipids and free and esterified cholesterol, reached significantly higher values postprandially in HF than in LF rabbits after $42 \mathrm{~d}$ feeding and later on. LDL-triacylglycerols showed an overall postprandial increase in HF rabbits as compared with $\mathrm{LF}$ rabbits after $14 \mathrm{~d}$ and later on, whereas LDL free and esterified cholesterol showed a significant increase at some time points. As compared with LF rabbits, fat-cholesterol feeding for 63 and $84 \mathrm{~d}$ in HF rabbits did not change HDLtriacylglycerols and -cholesterol esters postprandially, but significantly decreased HDLfree-cholesterol and increased HDL-phospholipids.

\section{Postprandial accumulation of radiolabelled dietary cholesterol and lipids in the plasma and lipoproteins}

Most but not all dietary ${ }^{14} \mathrm{C}$-labelled lipids ingested had left the stomach of LF and HF rabbits $34 \mathrm{~h}$ after meal intake (89.8 (SE 18.7) and 91.6 (SE 22.3) \% respectively) and only residual amounts were present in small intestine contents (1.3 (SE 0.2) \% and 1.6 (SE 0.8) \% respectively). Comparable figures were obtained for dietary $\left[{ }^{3} \mathrm{H}\right]$ cholesterol.

The radioactivity of $\left[{ }^{14} \mathrm{C}\right]$ oleic-acid-enriched lipids and $\left[{ }^{3} \mathrm{H}\right]$ cholesterol originating from the test meals slightly increased in the postprandial plasma of the LF rabbits (Fig. 2). Conversely, in the HF rabbits fed for $14 \mathrm{~d}$ (TM1-HF), a moderate but significant increase of radiolabelled plasma lipids was observed. A more marked and significant increase in the accumulation of radioactivity of $\left[{ }^{14} \mathrm{C}\right]$ oleic-acid-enriched lipids and $\left[{ }^{3} \mathrm{H}\right]$ cholesterol was observed postprandially in the plasma of the rabbits fed on the HF diet for $42 \mathrm{~d}$ (HF-TM3) 

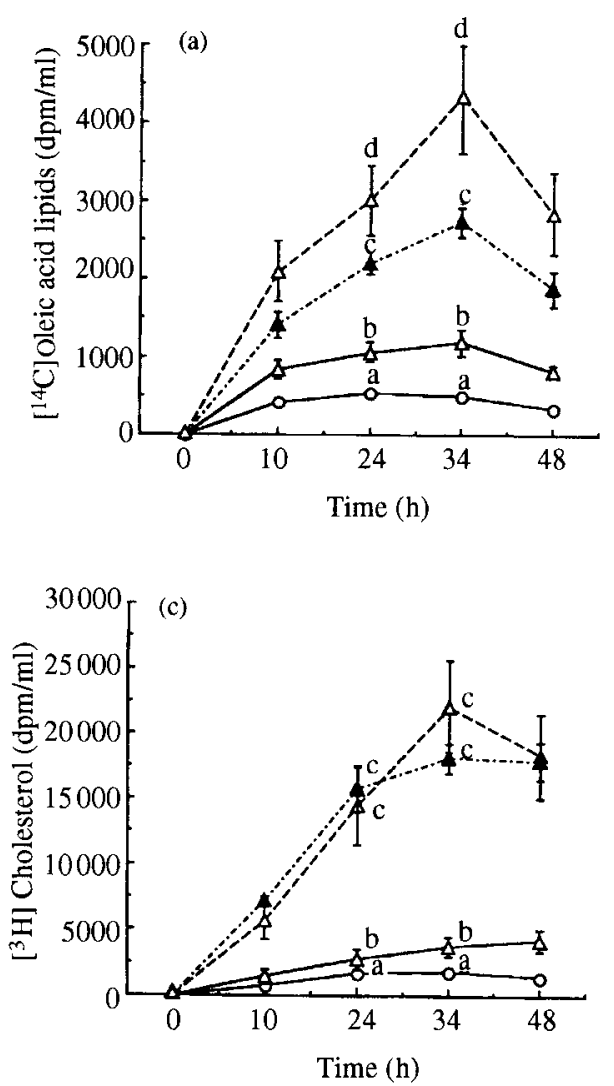

(b)

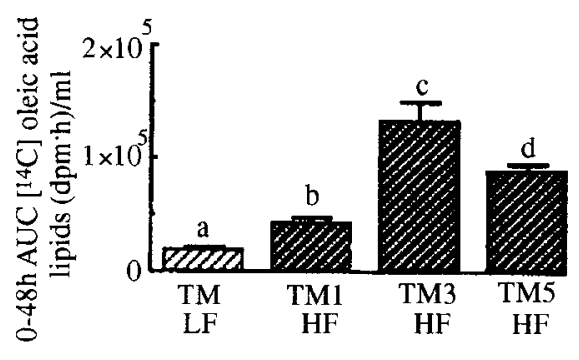

(d)

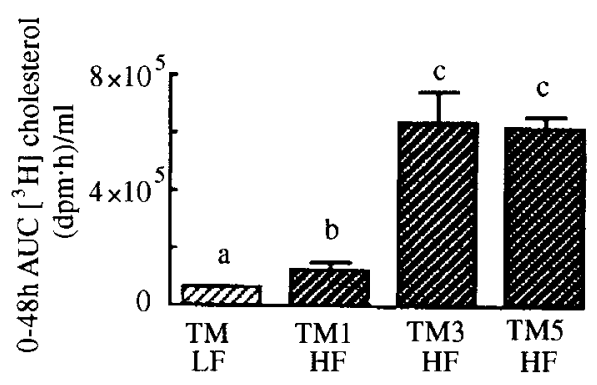

Fig. 2. (a) Plasma and $0-48 \mathrm{~h}\left[{ }^{14} \mathrm{C}\right]$ oleic acid lipid responses, (b) areas under the $0-48 \mathrm{~h}\left[{ }^{14} \mathrm{C}\right.$ loleic acid lipid curve (AUC) responses, (c) plasma $0-48 \mathrm{~h}\left[{ }^{3} \mathrm{H}\right]$ cholesterol responses and (d) $0-48 \mathrm{~h}$ AUC $\left[{ }^{3} \mathrm{H}\right]$ cholesterol responses to test meals containing $6 \mathrm{~g}$ fat and $0.2 \mathrm{~g}$ cholesterol given to rabbits fed on a low-fat control diet (LF-TM, $n$, 一 $-\mathrm{O}-$ ) or a high-fat, high-cholesterol diet (HF-TM1-5, $n$ 7). LF-TM values are means of test meals performed on days 0 and 63 . Test meals were given to rabbits of the HF group on days 14 (HF-TM1, $-\triangle-$ ), 42 (HF-TM3, - $\triangle--$ ) and 84 (HFTM5, ... $\Delta . \cdots)$. Values are means with their standard errors represented by vertical bars. ${ }^{\text {abcd }}$ Mean values with unlike letters were significantly different at a given time point (ANOVA for factorial non-repeated values and Fisher's test at a probability of $95 \%$ ).

or $84 \mathrm{~d}$ (HF-TM5). Plasma concentrations (Fig. 2) and the 0-48 h AUC (Fig. 2, (b and d)) exhibited comparable marked changes.

At the $34 \mathrm{~h}$ postprandial peak, the ${ }^{14} \mathrm{C}$ specific radioactivity (disintegrations/min per $\mu$ mol triacyglycerols) was significantly higher after test meals HF-TM3 and 5 (2534 (SE 500) and 1998 (SE 415)) than after HF-TM1 (1514 (SE 381)) or the LF-TM test meal (619 (SE 119) in control rabbits. No such differences were found for the specific radioactivity of plasma cholesterol postprandially.

The distributions of $\left[{ }^{14} \mathrm{C}\right]$ oleic-acid-enriched lipids and $\left[{ }^{3} \mathrm{H}\right]$ cholesterol in the different lipoprotein fractions $34 \mathrm{~h}$ postprandially was markedly affected by feeding the HF diet. In LF rabbits, only 27.6 (SE 6.9) and 35.8 (SE 5.7) \% of plasma radiolabelled lipids and cholesterol respectively, were present in TRL particles while the remainder was equally distributed between LDL and HDL. In HF rabbits (day 84), most plasma radiolabelled lipids and cholesterol were found in TRL particles (75.9 (SE 5.2) and 85.1 (SE 3.2)\% 
respectively), along with marginal amounts in HDL particles (12.7 (SE 3.1) and 3.8 (SE $1.0) \%$ respectively).

\section{Post-heparin plasma lipase activities}

Post-heparin plasma lipoprotein lipase and hepatic lipase activities were measured on day 105. Lipoprotein lipase and hepatic lipase activities were 70.9 (SE 4.3) and 6.2 (SE 1.0) mmol free fatty acids/1 per min respectively in the LF rabbits. In the HF rabbits, lipoprotein lipase and hepatic lipase activities were significantly higher, i.e. 128.2 (SE 7.8) and 11.6 (SE 1.5) mmol free fatty acids/1 per min respectively.

\section{Atheroma deposition}

At the completion of the experiment (day 119), the percentage of aorta surface occupied by lesions was quantified. The lesion development was not detectable in the arteries of the rabbits fed on the LF diet (detection level $0.1 \%$ of arterial surface). In contrast, all rabbits fed on the HF diet developed atheromatous lesions on the aorta (30.9 (SE 3.9) \% of total surface) and to a greater extent in the arch region.

\section{DISCUSSION}

The aim of the present study was to evaluate the effects of chronically feeding a high fat, high-cholesterol diet on the postprandial lipid response and atheroma deposition in adult rabbits. This animal species has already been widely used in nutritional and atheroma studies (Kritchevsky, 1991). Despite the limited information available on postprandial lipid metabolism in this species (Van Heek \& Zilversmit, 1990), it appeared that the rabbit would be a very interesting model given its long-lasting postprandial hyperlipidaemic phase. In fact, in the rabbits fed on a regular low-fat diet, assimilation of the standardized test meal $(6 \mathrm{~g}$ fat, $0 \cdot 2 \mathrm{~g}$ cholesterol) induced a small but significant increase in postprandial triacylglycerolaemia and TRL with a maximum value after $24 \mathrm{~h}$, which is much longer than in other species such as rat (Borel et al. 1989; Redard et al. 1992), pig (Luhman et al. 1992) or man (Cohn et al. 1988) in agreement with a previous study (Van Heek \& Zilversmit, 1990). This prolonged postprandial phase is probably related to a slow rate of gastric emptying in this species as measured here and by others (Van Heek \& Zilversmit, 1990).

While feeding the LF diet for 2 months did not alter the postprandial pattern, chronic feeding of a moderately fat-and-cholesterol enriched diet $(52 \mathrm{~g}$ fat $/ \mathrm{kg}$ and $1.7 \mathrm{~g}$ cholesterol $/ \mathrm{kg}$ ) (HF group) markedly altered the postprandial response. Until day 63, feeding the $\mathrm{HF}$ diet steadily increased the postprandial plasma triacylglycerol response to the test meal (up to 20-100\%). This postprandial rise originated from an exacerbated and specific accumulation of lipids containing radiolabelled fatty acids of dietary origin which especially accumulated in TRL particles, as did labelled cholesterol of dietary origin. Indeed, the increases in postprandial plasma triacylglycerols and radiolabelled dietary lipids were strongly correlated ( $r 0.80, P=0.05$ ) during the entire experimental period. Redistribution of lipid species of dietary origin between TRL sub-fractions probably occurred since the gastrointestinal handling of dietary lipids was not different in LF and HF rabbits. The most likely difference between the two groups of rabbits is expected to be their TRL clearance capacity in the postprandial state as shown directly by others with intravenously injected artificial chylomicrons or TRL (Mamo et al. 1991). 
Several concomitant events could have contributed to this lower clearance capacity. First, we observed a trend to increasing the $24 \mathrm{~h}$ fasting triacylglycerolaemia in HF rabbits after a sufficient feeding period: the peak triacylglycerol concentration in the postprandial period was positively correlated to the $24 \mathrm{~h}$ post-absorptive triacylglycerol $(r 0.81$, $P=0.03)$ and cholesterol $(r 0.76, P=0.05)$ concentrations. A correlation between postprandial and post-absorptive triacylglycerol concentrations has already been reported in human subjects (Cohn et al. 1988; Dubois et al. 1994). After chronic HF feeding, the endovascular lipolytic capacity, i.e. post-heparin lipoprotein lipase and hepatic lipase activities, approximately doubled in HF rabbits in agreement with the observations of others (Van Heek \& Zilversmit, 1990) but these rabbits were unable to clear dietary and endogenous plasma lipids efficiently postprandially. This is probably due to competition for lipolysis between TRL of intestinal and hepatic origin (Connelly et al. 1994), especially in this species with a low hepatic lipase activity (Chang \& Borensztajn, 1993).

Second, the dramatic postprandial and thus, $24 \mathrm{~h}$ post-absorptive, increase in TRL in HF rabbits could result from a defect in the uptake of lipoprotein remnants by the liver. The hepatic uptake of TRL (VLDL, $\beta$-VLDL and chylomicron remnants) is expected to be achieved through several receptor pathways. The impaired clearance of chylomicron remnants found in the homozygous LDL-receptor-defective rabbit (Demacker et al. 1992) as well as in rabbits with dietary cholesterol-induced down-regulation of LDL receptors (Mamo et al. 1991) supports the concept that apolipoprotein B/E receptor TRL uptake is partly achieved through this pathway. The increased accumulation of cholesterol in the liver observed in HF rabbits compared with LF (21.2 (SE 1.5) v. 6.3 (SE 0.5) $\mathrm{mg} / \mathrm{g}$ ) gives more weight to this possibility. Another pathway implicates an apolipoprotein E-richparticle receptor, such as the LDL-receptor-related protein (Hussain et al. 1995) or the lipolysis-stimulated receptor (Mann et al. 1995) but the dietary regulation of these receptors remains to be demonstrated in rabbits. Finally, clearance of hepatically derived $\beta$ VLDL particles by the liver through a specific receptor pathway (Kovanen et al. 1981) could be delayed in cholesterol-fed rabbits (Daugherty et al. 1985). In addition, transfer of cholesteryl esters from chylomicrons to LDL and $\beta$-VLDL (Stender \& Zilversmit, 1982) is associated with a reduced clearance of these particles.

As compared with LF rabbits, we observed in HF rabbits an increased accumulation of TRL particles especially enriched in fatty-acid containing lipids and cholesterol of dietary origin when increasing the duration of fat-cholesterol feeding. At the completion of the study (day 119), all HF rabbits exhibited a significant atheroma plaque deposition in the aorta (about one-third of the total surface) whereas the LF rabbits showed no quantifiable deposition. The build-up of atheromatous plaque on the aorta wall of lipid-fed rabbits has been reported previously (Kritchevsky, 1991; Daley et al. 1994) but the concomitant changes in postprandial lipaemia and atheroma deposition have not previously been described. More noticeably, these two phenomena have been found to be clearly related in HF rabbits. Indeed, the extent of atheroma deposition was positively correlated to the HFTM3 (day 42) postprandial $0-48 \mathrm{~h}$ AUC for (1) plasma total triacylglycerols $(r 0.61$, $P=0.03)$ and dietary fatty-acid-containing lipids $(r 0.54, P=0.04)$ and $(2)$ plasma total $(r$ $0.87, P=0.01)$ and dietary-derived cholesterol $(r 0.73, P=0.01)$. In fact, TRL particles and their remnants accumulate particularly in the plasma during the postprandial period as shown in the present study, a situation that dramatically raises the probability of lipoproteins penetrating the wall intima. The atherogenic potential of several kinds of triacylglycerol-rich particles has already been shown with different types of cultured cells such as macrophages (Gianturco \& Bradley, 1991) or smooth-muscle cells. At the same time, the esterified : free cholesterol ratio (results not shown) in LDL markedly increased 
under HF feeding in the postprandial and post-absorptive states, which increased the atherogenic capacity of these particles.

Among other species, rabbits are known to be sensitive to lipid intake and to develop atheroma deposition easily in the aorta. It is striking to observe that such an extraordinary sensitivity to atherosclerosis is associated with a noticeably long duration of the postprandial accumulation of dietary lipids and TRL particles in the plasma. According to Zilversmit's (1979) hypothesis that arteriosclerosis could be a postprandial phenomenon, the fat-cholesterol-fed rabbit appears to be an outstanding model by being permanently in a non-fasting hyperlipidaemic state. We suggest that the rabbit's well-known high capability to develop atheroma is related to a long-lasting postprandial state due to its poor ability to clear and handle absorbed dietary lipids. This observation is especially relevant given the fact that exaggerated and/or delayed postprandial lipaemia (Simpson et al. 1990; Patsch et al. 1992) is related to abnormalities in lipid metabolism or coronary events as well as to amounts of dietary lipids provided by meals in human subjects, as reviewed (Karpe \& Hamsten, 1995; Lairon, 1996). Taken together, the findings obtained in animal models and human subjects support the concept that postprandial lipaemia and lipoproteins are to some extent associated with the atherosclerotic process.

This work was supported by a grant from INSERM-FRSQ.

\section{REFERENCES}

Armand, M., Borel, P., Dubois, C., Senft, M., Peyrot, J., Salducci, J., Lafont, H. \& Lairon, D. (1994). Characterization of emulsions and lipolysis of dietary lipids in the human stomach. American Joumal of Physiology 266, G372-G381.

Belfrage, P. \& Vaughan, M. (1969). Simple liquid-liquid partition system for isolation of labeled oleic acid from mixture with triglycerides. Journal of Lipid Research 10, 311-313.

Borel, P., Lairon, D., Senft, M., Chautan, M. \& Lafont, H. (1989). Effect of wheat germ on the digestion and the intestinal absorption of dietary lipids in the rat. American Joumal of Clinical Nutrition 49, 1192-1202.

Buccolo, G. \& David, H. (1973). Quantitative determination of serum triglycerides by the use of enzymes. Clinical Chemistry 19, 476-482.

Cardin, A. D., Witt, K. R., Chao, J., Margolius, H. S., Donaldson, V. H. \& Jackson, R. L. (1984). Degradation of apolipoprotein B-100 of human plasma low density lipoproteins by tissue and plasma kallikreins. Journal of Biological Chemistry 259, 8522-8528.

Chang, S. \& Borensztajn, J. (1993). Hepatic lipase function and the accumulation of $\beta$-very-low-density lipoproteins in the plasma of cholesterol-fed rabbits. Journal of Biochemistry 293, 745-750.

Cohn, J. S., McNamara, J. R., Cohn, S. D., Ordovas J. M. \& Schaefer, E. J. (1988). Postprandial plasma lipoprotein changes in human subjects of different ages. Journal of Lipid Research 29, 469-479.

Connelly, P., Maguire, G., Vezina, C., Hegele, R. \& Kuksis, A. (1994). Kinetics of lipolysis of very low density lipoproteins by lipoprotein lipase. Journal of Biochemistry 269, 20554-20560.

Daley, S., Herderick, E., Cornhill, J. \& Rogers, K. (1994). Cholesterol-fed and casein-fed rabbit models of atherosclerosis. Arteriosclerosis and Thrombosis 14, 95-104.

Daugherty, A., Lange, L. G., Sobel, B. E \& Schonfeld, G. (1985). Aortic accumulation and plasma clearance of $\beta$-VLDL and HDL: effects of diet-induced hypercholesterolemia in rabbits. Journal of Lipid Research 26, 955-963.

Demacker, P., Van Heijst, P. \& Stalenhoef, F. (1992). A study of the chylomicron metabolism in WHHL rabbits after fat loading. Journal of Biochemistry 285, 641-646.

Dubois, C., Armand, M., Azais-Braesco, V., Portugal, H., Pauli, A.M., Bernard, P.M., Latgé, C., Lafont, H., Borel, P. \& Lairon, D. (1994). Effects of moderate amounts of emulsified dietary fat on postprandial lipemia and lipoproteins in normolipemic adults. American Journal of Clinical Nutrition 60, 374-382.

Folch, J., Lees, M. \& Sloane-Stanley, G. H. (1957). A simple method for isolation and purification of total lipids from animal tissue. Journal of Biological Chemistry 226, 498-509.

Gianturco, S. H. \& Bradley, W. A. (1991). A cellular basis for atherogenicity of triglyceride-rich lipoproteins. Atherosclerosis Review 22, 9-14.

Holman, R. L., McGill, H. C. \& Strong, J. P. (1958). Technics for studying atherosclerotic lesions. Laboratory Investigation 7, 42-47. 
Hussain, M., Innerarity, T. L., Brecht, W. J. \& Mahley, R. W. (1995). Chylomicron metabolism in normal, cholesterol-fed rabbits, and Watanabe heritable hyperlipidemic rabbits. Saturation of the sequestration step of the remnant clearance pathway. Journal of Biological Chemistry 270, 8578-8587.

Karpe, F. \& Hamsten, A. (1995). Postprandial lipoprotein metabolism and atherosclerosis. Current Opinion in Lipidology 6, 123-129.

Kovanen, P., Brown, M., Basu, S., Bilheimer, D. \& Goldstein, J. (1981). Saturation and suppression of hepatic lipoprotein receptors: a mechanism for the hypercholesterolemia of cholesterol-fed rabbits. Proceedings of the National Academy of Sciences USA 78, 1396-1400.

Kritchevsky, D. (1991). Dietary fat and experimental atherosclerosis. International Journal of Tissue Reactions $13,59-65$.

Lairon, D. (1996). Nutritional and metabolic aspects of postprandial lipemia. Reproduction Nutrition Développement 36, 345-355.

Luhman, C. M., Faidley, T. D. \& Beitz, D. C. (1992). Postprandial liporotein composition in pigs fed diets differing in type and amount of dietary fat. Journal of Nutrition 122, 120-127.

Mamo, J. C. L., Bowler, A., Elsegood, C. L. \& Redgrave, T. (1991). Defective plasma clearance of chylomicronlike lipid emulsions in WHHL rabbits. Biochimica et Biophysica Acta 1081, 241-245.

Mann, C. J., Khallou, J., Chevreuil, O., Troussard, A. A., Guermani, L. M., Launay, K., Delplanque, B., Yen, F. T. \& Bihain, E. B. (1995). Mechanism of activation and functional significance of the lipolysis-stimulated receptor. Evidence for a role as chylomicron remnant receptor. Biochemistry 34, 10421-10431.

Murphy, M. C., Isherwood, S. G., Sethi, S., Gould, B. J., Wright, J. W., Knapper, J. A. \& Williams, C. M. (1995). Postprandial lipid and hormone responses to meals of varying fat contents: modulatory role of lipoprotein lipase? European Journal of Clinical Nutrition 49, 579-588.

Patsch, J. R., Miesenboch, G., Hopferwiser, T., Mühlferger, V., Knapp, E., Dunn, J. K., Gotto, A. M. \& Patsch, W. (1992). Relation of triglyceride metabolism and coronary artery disease. Studies in the postprandial state. Arteriosclerosis and Thrombosis 12, 1336-1345.

Redard, C. L., Davis, P. A, Middleton, S. J. \& Schneeman, B. O. (1992). Postprandial lipid response following a high fat meal in rats adapted to dietary fiber. Journal of Nutrition 122, 219-228.

Redgrave, T. G., Roberts, D. C. K. \& West, C. E. (1975). Separation of plasma lipoproteins by density gradient centrifugation. Analytical Biochemistry 65, 42-49.

Seidel, J., Hagele, E. O., Zingenhorn, J. \& Wahlfeld, A. W. (1983). Reagent for the enzymatic determination of serum total cholesterol with improved lipolytic efficiency. Clinical Chemistry 29, 1075-1080.

Simpson, H. S., Williamson, C. M., Olivecrona, T., Pringle, S., Maclean, A. R., Lorimer, A. R., Bonnefous, F., Bogaievsky, Y., Packard, C. J. \& Shepherd, J. (1990). Postprandial lipemia, fenofibrate and coronary artery disease. Atherosclerosis 85, 193-202.

Stender, S. \& Zilversmit, D. (1982). Comparison of cholesteryl ester transfer from chylomicrons and other plasma lipoproteins to aortic intima media of cholesterol-fed rabbits. Arteriosclerosis 2, 493-499.

Takayama, M., Itoh, S., Nagasaki, T. \& Tanimizu, I. (1977). A new enzymatic method for choline containing phospholipids. Clinica Chimica Acta 79, 93-98.

Van Heek, M. \& Zilversmit, D. B. (1990). Postprandial lipemia and lipoprotein lipase in the rabbit are modified by olive and coconut oil. Arteriosclerosis 10, 421-429.

Warren, R., Ebert, D., Barter, P. \& Mitchell, A. (1991). The regulation of hepatic lipase and cholesteryl ester transfer protein activity in the cholesterol fed rabbit. Biochimica et Biophysica Acta 1086, 354-358.

Winer, B. J. (1971). Statistical Principles in Experimental Design. New York: McGraw-Hill.

Zilversmit, D. B. (1979). Atherogenesis: a postprandial phenomenon. Circulation 60, 473-485. 